\title{
The design of the Ideological and Political Courses Based on the teaching of Multidimensional Seminar teaching Model
}

\author{
Ying $L i^{1, a}$ \\ ${ }^{1}$ Yunnan Marxism College of Qujing Normal University, China \\ a $845471257 @$ qq.com
}

Keywords: multidimensional seminar teaching model, ideological and political course

\begin{abstract}
Using the multidimensional seminar teaching model in ideological and political courses can improve the courses's efficient and practical relevance. In this paper, put forward nine seminar teaching model including open-ended seminar, investigation-based seminar, network-based seminar , interaction-based seminar , case-based seminar , survey-based seminar , competition-based seminar, team-based seminar and analog-based seminar. According to the difficulty,the emphasis , the social aroused general interest of the ideological and political teaching , he nine multidimensional seminar teaching model can be combined freely and the teaching assessment methods are adjusting accordingly . The multidimensional seminar teaching model need the teachers must improve their teaching capability and the students must improve their capability of combining theory and practice.
\end{abstract}

\section{Introduction}

Ideological and political courses is the obligatory politics courses ,and it include the moral cultivation legal basis course ,the Mao zedong thought and socialism with Chinese characteristics course, the basic principles of Marxism course and the China 's modern history course . The content of the four courses are different,so the teaching process of the four courses are different and they must have different features , And according to the features of the ideological and political course ,we must research the efficient teaching method .

Multidimensional seminar teaching method is the efficient means of achieving the teaching purpose of the ideological and political course

In 2010 year, the State Council publish the education correction and development compendium, and in this compendium stipulate that improving the education quality is the kernel assignment of the education. And most of students must study ideological and political course,the continuing and ideological and political course will effect the teaching quality of the course ${ }^{[1]}$.and it is important that make the teaching content innovate . The expert of American Beeby.C.E suppose that we should think over the teaching level from three different aspect,and the first aspect is the most simple level that is the quality of course conception, it grasp the simple technical ability and knowledge ,the second aspect is the survey to teaching quality and the economy expect expert think that that is the quality of ideological and political course ,the third aspect is the teaching quality that social and person thought. So from the education subject, the teaching quality have three aspect including subject conception, market conception and schoolroom conception ${ }^{[2-3]}$. And the multidimensional seminar teaching method is different with the traditional teaching method,the detailed information is in map .1 
Map.1 the different between multidimensional seminar and traditional teaching method

\begin{tabular}{|l|l|l|l|}
\hline Name & $\begin{array}{l}\text { Teaching } \\
\text { focal point }\end{array}$ & $\begin{array}{l}\text { The status of teachers } \\
\text { and students }\end{array}$ & The evaluation of teaching \\
\hline $\begin{array}{l}\text { Traditional } \\
\text { teaching method }\end{array}$ & $\begin{array}{l}\text { Emphasis } \\
\text { teaching the } \\
\text { known } \\
\text { knowledge }\end{array}$ & $\begin{array}{l}\text { The center is } \\
\text { teachers ,the students } \\
\text { is the accepted people } \\
\text { of knowledge }\end{array}$ & $\begin{array}{l}\text { The evaluation process is } \\
\text { rounding a correct solution }\end{array}$ \\
\hline $\begin{array}{l}\text { Multidimensional } \\
\text { seminar teaching } \\
\text { method }\end{array}$ & $\begin{array}{l}\text { Emphasis } \\
\text { the ability of } \\
\text { solving } \\
\text { problem }\end{array}$ & $\begin{array}{l}\text { The center is the } \\
\text { students the teachers } \\
\text { s function is to } \\
\text { promote and guide } \\
\text { students }\end{array}$ & $\begin{array}{l}\text { Emphasis the display at } \\
\text { the evaluation process }\end{array}$ \\
\hline
\end{tabular}

The teaching content of ideological and political course is provided with stronger developed under the examination education, we should improve the teaching quality of the ideological and political course and consider the knowledge of the course, the reality of social and the different of the students to achieve the goal of cultivating students. Only in this way ,can the students ensure they face things positive .

\section{The multidimensional seminar teaching model is the key means to achieve the teaching goal of ideological and political course}

Under the guide of teachers ,the seminar teaching must make the students as the key factor in the ideological and political course. The students will know they should how to learn through that they discovery the solving methods by themselves. The multidimensional seminar teaching changed the traditional teaching model and it can elaborate the subjective dynamic role. The different multidimensional seminar teaching models are designed based on different teaching content and teaching features, it can promote the communication between the students and the teachers, and it can make the students learn the knowledge quickly. And you can find the $t$ teaching process is the figure .1 .

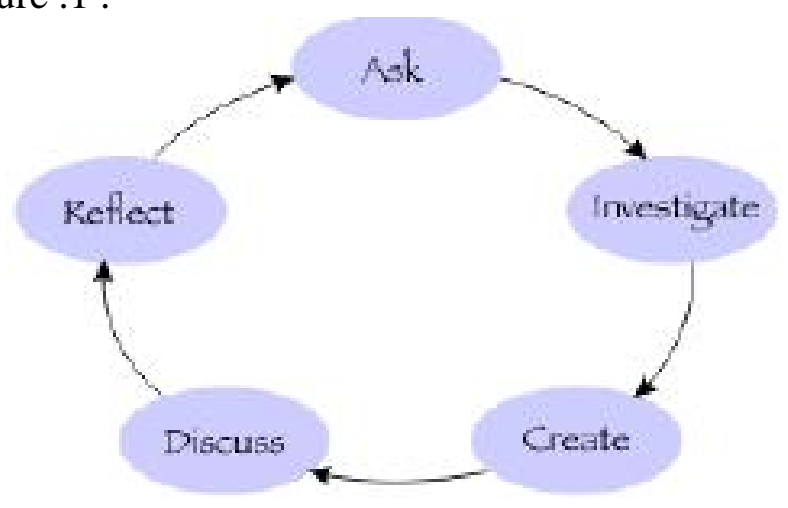

Figure .1 The multidimensional seminar teaching process

\section{Using multidimensional seminar teaching model in the ideological and political course teaching}

The investigation-based seminar teaching model. The investigation-based seminar teaching model make us achieve a lot of positive result in teaching theory and teaching practice. it can resolve the specific teaching assignment, and you can find it in the teaching process that teachers 
explain the important content in the class. The teachers can make the students to consider the content that they can not learn the content quickly before teachers explaining this content, so the teacher and the students can communicate rounding this content on the next class.

The opened-based seminar teaching model. In the process of discussing the problem,the students can say out their view. It need students to prepare problem before teachers explaining the relate discussing problem. And the teachers should encourage students to express their view and positively cultivate students ' interests that take more attention to the great event of China and foreign.$^{[4]}$

The network -based seminar teaching model. The network -based seminar teaching model achieve the teaching goal by developing network,and it is the spread of the tradition teaching . In the university, the students have three class hour to learn the ideological and political courses,the limited study time in class make students can not learn the content quickly ,and the network-based seminar teaching model can help solve the problem . And the process of net-work-based seminar teaching model is the figure. 2 .

The case-based seminar teaching model. The case-based seminar teaching model is usually found in the teaching of ideological and political courses. It has many advantage that can simulate the reality by with the help of case.

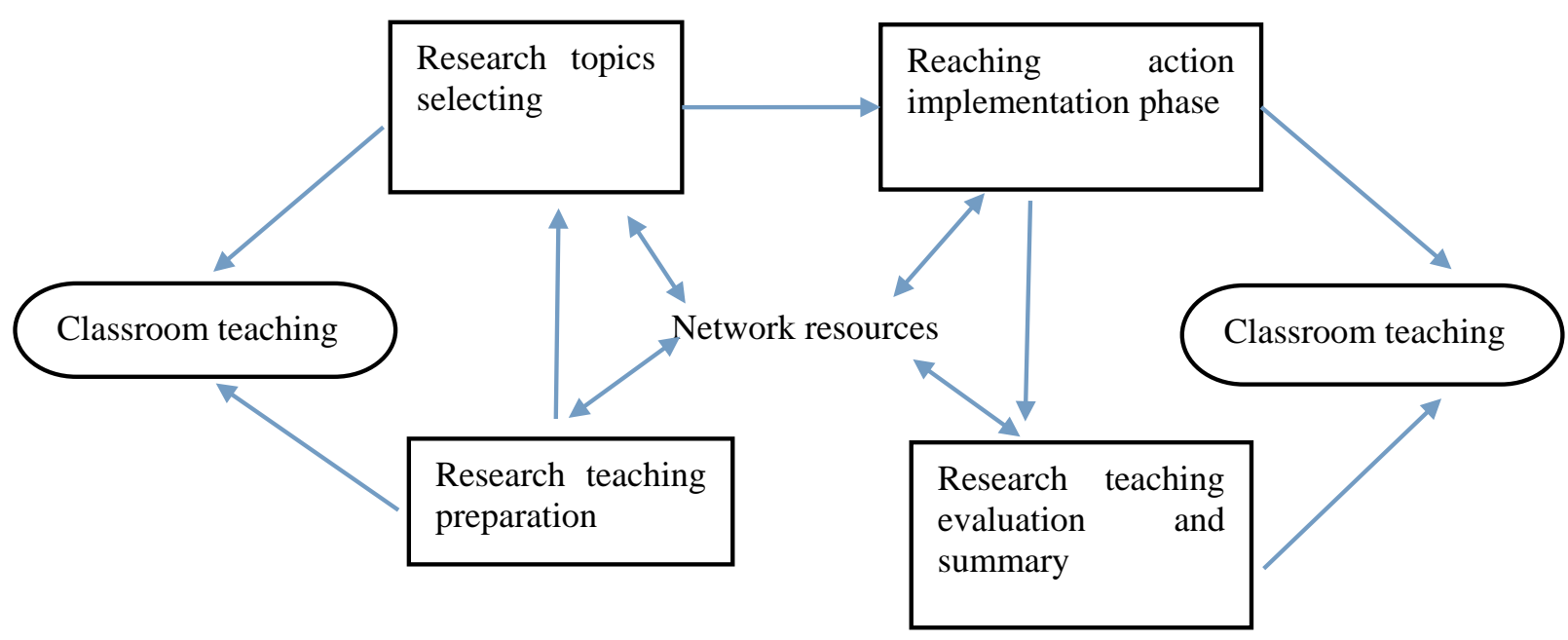

Figure 2 the process of the network-based seminar model

\section{Conclusions}

According to the traditional teaching model of ideological and political courses, research the multidimensional seminar model to improve the teaching quality,the teaching model can help the students to learn the content of ideological and political courses quickly .

\section{Acknowledgements}

Supported by the eleventh five-year plan project of education science of Yunnan province: Research on evaluation and incentive mechanism of College teachers under Appointment system (GY100052)

\section{References}

[1] Spruijt Annemarie, Wolfhagen ineke, Bok Harold, Schuurmans Eva:Teacher's perception of aspects seminar learning :a qualitative . Jaarsma Debbie BMC Medical Education, Vol. 27(2013) No. 4, P.35-39. 
[2] Van Beukelen P : Students ' perceptions of aspects affecting seminar learning . Scherpbier A J J A Medical Teacher,Vol .2(2012). No .12:145-149 .

[3] Tokarev lu N: Experience with ideological political education at the school for nurses and feld shere of the S.P.B otkin Hospital, Vol . 45 (1954) . No .15 : 1234-1245.

[4] David S.Jakes , Mark E. Penington , Howard A.Knodle . Using the Internet to promote Inquiry-based learning. Sgan-Cohen Harold Dental Traumatology ,Vol .12 No .6 , P.123-128 . 